\title{
Anti-PD-1-Targeted Therapies Focusing on Lymphatic Malignancies: Biological Rationale, Clinical Challenges and Opportunities
}

\author{
Meirav Kedmi Abraham Avigdor Arnon Nagler \\ Hematology Division, Chaim Sheba Medical Center, Tel Hashomer, and Sackler School of Medicine, Tel Aviv \\ University, Tel Aviv, Israel
}

\section{Key Words}

Chronic lymphoid leukemia - Lymphoma · Multiple myeloma · PD-1 · PD-L1 · PD-L2

\begin{abstract}
Cancer immunotherapy with tumor-directed antibodies has generally been very successful, while T-cell immunotherapy has been less effective. Some lymphoid malignancies can be cured with immunochemotherapy but nevertheless many patients relapse or progress in spite of maximal therapy. Both solid tumors and lymphoid malignancies develop mechanisms in order to escape destruction by the intact immune system. One such mechanism is mediated through immune checkpoints. PD-1 (programmed cell death protein-1, which is expressed on activated T and B cells, natural killer cells and myeloid cells, is one of those checkpoints. This review focuses on the effect of PD-1 activation on lymphoid malignancies and its role as a therapeutic target.
\end{abstract}

(c) 2014 S. Karger AG, Basel

\section{Introduction}

T-cell activation requires the presentation of an antigen to the T-cell receptor (TCR), via an antigen-presenting cell (APC) in the presence of a major histocompatibility complex (MHC) molecule. Co-stimulatory molecule interactions, such as cluster of differentiation 28 (CD28) on the T cell and CD80 (B7.1) or CD86 (B7.2) on the APC are also required in order to achieve clonal $\mathrm{T}$-cell proliferation and cytokine production $[1,2]$. T-cell activation is balanced by numerous inhibitory signals (immune checkpoints) aimed at maintaining self-tolerance and preventing tissue damage to the host as a result of overreaction of the immune system [3]. A major immune checkpoint with recent therapeutic implication is cytotoxic T-lymphocyte antigen 4 (CTLA-4). This protein binds to B7.1 and B7.2 with greater affinity than CD28 and suppresses T-cell response [4-6].

Programmed cell death protein-1 (PD-1) and its ligands is another immunological checkpoint that, in contrast to CTLA-4, limits T-cell response in the tissues and not in the initial activation phase [7]. The PD-1 gene belongs to the immunoglobulin gene super family and encodes a $55 \mathrm{kDa}$ type I transmembrane protein $[8,9]$. The protein's structure includes an extracellular IgV domain followed by a transmembrane region and a cytoplasmic tail. The intracellular tail contains two phosphorylation sites, one located in an immunoreceptor tyrosine-based inhibitory motif (ITIM) and the other in an immunoreceptor tyrosine-based switch motif (ITSM), which suggests that PD-1 negatively regulates TCR signaling [10]. The ITIM motif of PD-1 is thought to mediate inhibitory signals while the ITSM motif is thought to be responsible for signaling after PD-1 ligation [11]. PD-1 is expressed on thymocytes, activated mature $\mathrm{T}$ and $\mathrm{B}$ cells, as well as on NK and myeloid cells [12].

\section{KARGER 125}

(C) 2014 S. Karger AG, Base

0001-5792/14/1332-0129\$39.50/0
Prof Arnon Nagler, MD, MSc

Hematology Division

Chaim Sheba Medical Center, Tel Aviv University

Tel Hashomer 52621 (Israel)

E-Mail Arnon.Nagler@ sheba.health.gov.il 
Fig. 1. Interaction between PD-1 and PDL1 leads to immunological shutdown: blockade of this interaction leads to activation of the immune system.

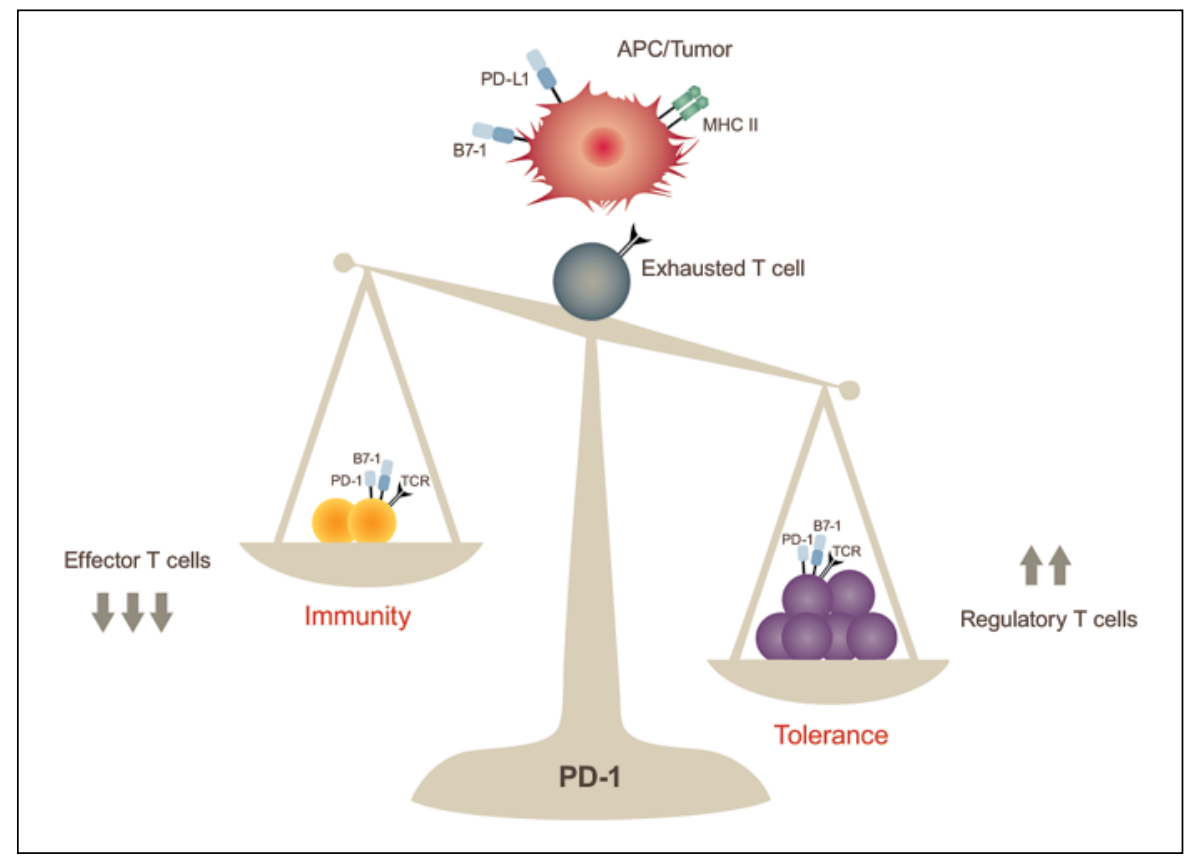

Two ligands for PD-1 have been identified; PD-L1 and PD-L2. Both these ligands belong to the B7 family [13], in which eight transmembrane proteins that influence immune response and deliver co-stimulatory or co-inhibitory signals have been identified so far [14]. PD-L1 and PD-L2 are type I transmembrane glycoproteins composed of IgC- and IgV-type extracellular domains that share $40 \%$ amino acid sequence identity $[13,15]$. PD-L1 is constitutively expressed on endothelial cells, heart, lung, placental, and pancreatic cells, as well as on B, T, dendritic, and myeloid cells, while PD-L2 is mostly expressed on hematopoietic cells [16]. PD-L1 and PD-L2 are upregulated in response to interferon- $\gamma$ as well as other triggers. In vitro, the engagement of PD-1 by PD-L1 induces phosphorylation of the ITIM and ITSM motifs, which results in inhibition of the PI3K/Akt pathway, reduces TCR-mediated lymphocytic proliferation and interferon- $\gamma$ secretion, and increases T-cell apoptosis [13]. Interaction between PD-1 with either one of its ligands has been described to downregulate TCR-mediated lymphocyte proliferation and survival, and inhibit cytokine production by CD4+ and CD8+ T cells [13]. PD-1 ligand interaction has also been shown to inhibit virusspecific CD8+ T-cell proliferation. This effect can be reversed by blocking the interaction [17].

Petrovas et al. [18] found that PD-1 is a major regulator of apoptosis that impacts the frequency of antiviral $\mathrm{T}$ cells in HIV, and that it could be manipulated to improve
HIV-specific CD8+ T-cell numbers. PD-1 knockout mice develop glomerulonephritis and other lupus-like phenomena, as well as lymphoproliferative diseases $[19,20]$. Therefore, it was suggested that PD-1 mediates maintenance of peripheral self-tolerance and serves as a general negative regulator of immune responses [19].

\section{Blocking the PD-1 Immune Checkpoint in Cancer Immunotherapy}

The paradigm of immunotherapy for cancer relies on the concept that re-activation of the silenced immune system against tumor cells can result in better tumor control (fig. 1).

Inhibiting the factors that are responsible for T-cell paralysis and immune tolerance is the subject of thorough investigation. Immune checkpoint proteins can be manipulated by tumors as an immune resistance mechanism. Most efforts to manipulate antitumor activity have focused on T cells (e.g. cytotoxic CD8+ T cells) because of their ability to directly eradicate cells that present certain antigens. T-cell inhibitory ligands are overexpressed on tumor cells, with the PD-L1 antigen particularly overexpressed in solid tumors [21]. Immunohistochemistry (IHC) techniques have shown that PD-L1 is constitutively expressed on multiple human tumors [21]. In some cases, correlation has been 
found between PD-L1 expression on tumor cells and prognosis [22-24]. However, the cut-point to define PD-L1 positivity has not yet been validated in any solid tumor. There are also some technical obstacles to the utility of IHC in this context.

Tumor-infiltrating lymphocytes invade many kinds of tumors and express high levels of PD-1 $[25,26]$ while myeloid and dendritic cells in the tumor microenvironment express PD-L1, and blockage of PD-L1 improved their antitumor activity [27]. PD-L1 expression on tumor cells can be either an adaptive response to resist immune attack or constitutive expression resulting in ongoing processes as in BRAF V600 melanoma [28], with both mechanisms probably contributing to the expression of PD-L1 on human cancers. Therefore, PD-1 and PD-L1 serve as attractive targets for antibody development in an attempt to blockade their interaction and so increase immune response and better control cancer [29].

Several clinical studies explored the efficacy of antiPD-1 and anti-PD-L1 antibodies in advanced solid tumors. In a dose-escalating phase I trial using the highaffinity, human, PD-L1-specific IgG4 monoclonal antibody BMS936559, Brahmer et al. [30], demonstrated its significant effectiveness in patients with advanced melanoma, renal cell carcinoma (RCC), or non-small-cell lung cancer (NSCLC).

Topalian et al. [31] reported their experience in 296 patients with advanced melanoma, NSCLC, castrationresistant prostate cancer, RCC, or colorectal cancer treated with anti-PD-1 IgG4 fully human antibody, BMS-936558 (nivolumab, MDX-1106). They witnessed objective responses in $20-25 \%$ of the patients with NSCLC, melanoma, or RCC. The toxicity profile was favorable. The results from this study were recently updated for the 107 melanoma patients. The authors indicate that median overall survival was 16.8 months across doses and 20.3 months at the $3 \mathrm{mg} / \mathrm{kg}$ dose, 44 and $40 \%$ of patients were alive at 2 or 3 years, respectively [32]. BMS-936558 was also given to 33 metastatic, multiply treated RCC patients at two different doses. Responses were observed in 8 patients at both doses and side effects were tolerable [33]. Nivolumab was also studied in 39 patients with advanced metastatic melanoma, colorectal cancer, castration-resistant prostate cancer, NSCLC, or RCC in a phase I dose-escalating trial. The antibody was well tolerated and objective responses were observed [34].

Lambrolizumab (MK-3475), an IgG4 anti-PD-1 monoclonal antibody, was also evaluated in a phase I dose-escalating clinical trial on patients with advanced

Anti-PD-1 Therapy for

Lymphoproliferative Diseases melanoma, sarcoma, carcinoid, rectal cancer, or NSCLC. The antibody was well tolerated at all three doses and antitumor activity was also observed [35].

\section{PD-1/PD-L1 in Lymphoproliferative Malignancies and Multiple Myeloma}

The importance of the PD-1 axis in lymphoproliferative diseases has been demonstrated in multiple different scenarios. PD-1 was shown to be highly expressed on adult T-cell leukemia lymphoma cells (ATLL). A significant difference between the expression of PD-1 on normal controls, HTLV1 asymptomatic carries and ATLL patients has been found. Normal controls had much lower expression of PD-1 on their cytotoxic T cells. These finding may indicate the importance of PD-1/PD-L1 in turning HTLV1 to chronic infection and escape of ATLL from the host immune system [36]. PD-1 is also invariably expressed on angioimmunoblastic T-cell lymphoma and anaplastic large cell lymphoma $[37,38]$.

With respect to B-cell non-Hodgkin lymphomas (non$\mathrm{HL}$ ), it has been shown that PD-1 is expressed on small lymphocytic lymphoma and chronic lymphoid leukemia (CLL) cells, grade III follicular lymphoma (FL) and, in some cases, on diffuse large B-cell lymphoma (DLBCL). Mantle cell lymphoma and marginal zone lymphoma have not been shown to express PD-1 [37]. Both PD-L1 and PD-L2 were found to be aberrantly expressed on CLL cells [39]. There were also indications of a causal relationship between CLL and PD-1/PD-L1/L2-mediated T-cell dysfunction [39]. Ramsay et al. [40] demonstrated that expression of PD-1 on circulating T lymphocytes and of PD-L2 on CLL and FL cells is higher than in normal controls.

The role of intratumoral PD-1+ T cells and their contribution to patient outcome in FL is disputed. Some studies found that increased numbers of PD-1+ T cells correlate with an inferior prognosis [41] while other studies found that PD-1 expression is related to better outcomes [42]. Carreras et al. [43] examined 132 biopsies of FL at diagnosis and first relapse. The cells were stained with anti-PD-1 antibody in order to evaluate the impact of immunoregulatory lymphocytes on the outcome using quantitative image analysis. The authors found that high expression (>33\%) of PD-1 correlated with prolonged progression-free survival (PFS), while low expression $(<5 \%)$ correlated with a high risk of transformation. This finding was recently validated by Takahashi et al. [44] in a study performed on post-rituximab era samples from 
FL patients. Using flow cytometry, Yang et al. [45] recently found that PD-1 is expressed on two different intratumoral T-cell populations. $\mathrm{PD}$-1-bright $\mathrm{T}$ cells are found within the follicle, while PD-1-dim T cells are exhausted $\mathrm{T}$ cells that are predominantly present in the interfollicular space. It seems that PD-1-dim cells confer a worse prognosis, while PD-1-bright cells may actually be associated with a better outcome. These findings may partially explain the inconsistencies in the literature regarding the impact of PD-1+ cells on outcome in FL.

PD-L1 expression was demonstrated to be upregulated in Hodgkin lymphoma (HL) cell lines, as well as on HL Reed-Sternberg cells. PD-1 was also found to be elevated on tumor-infiltrating T lymphocytes in HL. Blockade of the PD-1 signaling pathway inhibited interferon- $\gamma$ production by HL-infiltrating T cells. The authors indicated that the deficient cellular immunity observed in HL patients can be explained by 'T-cell exhaustion' which is led by activation of the PD-1/PD-L1 signaling pathway [46].

Nodular sclerosis classical HL and primary mediastinal B-cell lymphoma (PMBCL) have clinical, pathological, and molecular similarities. In a pathological study, Green et al. [47] indicated an increased PD-1 expression in both. They also demonstrated that structural amplification of chromosome 9p24.1 increases the abundance of both PD-1 ligands and, on this basis, suggest that PD-L1 and PD-L2 might serve as targets for therapeutic intervention.

Using novel antibodies and formalin-fixed, paraffinembedded tissue biopsies from 237 patients, Chen et al. [48] were able to show robust expression of PD-L1 in classical HL, PMBCL, Epstein-Barr virus-positive DLBCL, plasmablastic lymphoma, human herpesvirus-8-associated effusion lymphoma, and extranodal natural killer $(\mathrm{NK}) / \mathrm{T}$-cell lymphoma. Both the tumor cells and the tumor-invading macrophages expressed PD-L1 in these lymphomas. PD-L1 was not detectable in DLBCL - not otherwise specified, Burkitt lymphoma, or nodular lymphocyte predominant HL. They concluded that some virus/immunodeficiency-related lymphomas should be targeted with anti-PD-L1 therapies.

Using IHC and flow cytometry, Grote et al. [49] tested six Waldenström macroglobulinemia bone marrows for PD-1 and PD-L1/L2 expression. While PD-1 expression in these marrows was not significantly different from controls, PD-L1 and PD-L2 expression was significantly higher, with the ligands being expressed on malignant $B$ cells as well as on macrophages and dendritic cells.

Multiple myeloma (MM) is an incurable plasma cell dyscrasia. The adaptive immune system is clearly capable of attacking malignant plasma cells, however the pro- found immune dysregulation in this disease enables tumor escape from the immune system. PD-L1 is absent on normal plasma cells whereas it is present on MM cell lines $[50,51]$. Growth of the myeloma cells in normal syngeneic mice was transiently inhibited by the administration of anti-PD-L1 antibody in vivo and was completely suppressed in syngeneic PD-1-deficient mice [50].

T cells from myeloma-bearing mice express high levels of PD-1. This finding has also been observed in patients with MM. Those T cells were shown to be exhausted and to produce interleukin-10 [52]. Based on these observations, the authors used a combination of hematopoietic stem cell transplantation with whole-cell vaccination and PD-L1 blockade and demonstrated increased survival of the myeloma-bearing mice from 0 to $40 \%$ [52].

Kearl et al. [53] demonstrated in a murine model that PD-1/PD-L1 blockade with a PD-L1-specific antibody elicits rejection of a murine myeloma when combined with lymphodepleting irradiation. In vivo depletion of CD4+ or CD8+ T cells completely eliminated the antitumor efficacy of the lymphodepletion/anti-PD-L1 therapy, indicating that both T-cell subsets are necessary for tumor rejection. Elimination of myeloma by $\mathrm{T}$ cells occurred within 5 days of the first anti-PD-L1 treatment, suggesting that anti-myeloma reactivity is primarily mediated by pre-activated $\mathrm{T}$ cells, rather than by newly generated myeloma-reactive $\mathrm{T}$ cells.

NK cells from MM patients express PD-1. It may be that the PD-1/PD-L1 interaction hampers the control of MM by NK cells [54]. This was supported by the finding that pidilizumab (CT-011), a humanized IgG1 monoclonal antibody to PD-1, was able to induce effective NK cell activity against MM cells [54]. Lenalidomide was shown in the same study to reduce PD-L1 expression on MM cells [54]. Lenalidomide administration also resulted in a decrease in the expression of PD- 1 on T cells and induced amplified responses to MM vaccine [55]. Together, these findings suggest that lenalidomide enhances the immunological response to MM through the PD-1 cascade.

\section{Clinical Experience with PD-1/PD-L Blockade in Lymphoproliferative Diseases and Multiple Myeloma}

The first attempt to treat hematological malignancies with anti-PD-1 antibody was perused by Berger et al. [56]. They published their experience with pidilizumab (CT011), a humanized IgG1 monoclonal antibody to PD-1, in a phase I trial for patients with advanced hematological 
malignancies. 17 patients with AML, CLL, non-HL, HL, and $M M$ were given escalating single doses $(0.2-6 \mathrm{mg} / \mathrm{kg})$ of pidilizumab. The study indicated that the antibody was safe and no single maximal tolerated dose was defined. Disease control was achieved in $33 \%$ of patients. One patient with FL achieved complete response [56].

Based on these data and results in animal models for FL, Westin et al. [57] conducted a phase II clinical trial in which they administered pidilizumab (i.e. CT-011) and rituximab to relapsed FL patients who had undergone 1-4 prior therapies. 30 patients were enrolled and 1 patient was withdrawn after the first infusion of pidilizumab and received other treatment based on the decision of the treating physician. Thus, 30 patients were evaluable for toxicity and 29 patients were eligible for efficacy analysis. Pidilizumab was administered at $3 \mathrm{mg} / \mathrm{kg}$ every 4 weeks for up to 12 infusions. Rituximab was dosed at $375 \mathrm{mg} / \mathrm{m}^{2}$ once weekly for 4 weeks starting on day 17 and ending on day 38 after the first infusion of pidilizumab. The study demonstrated an overall response rate of $66 \%$, with $52 \%$ of participants achieving a complete response. No grade 3-4 side effects were observed. Responding patients had significantly higher levels of PD-L1 expression on their CD4+, CD8+ and CD14+ cells in the peripheral blood. Tumor response and PFS were associated with $\mathrm{T}$-cell activation gene signatures in tumor gene expression profiling data at baseline. Comparison of baseline and day 14 postpidilizumab samples demonstrated increased expression of T-cell activation associated genes post-therapy [58].

In an editorial linked to this work, Bachy and Coiffier [59] commented that, although the relationship between the tumor and the microenvironment in FL is complex and the involvement of other pathways in the response cannot be ruled out, the results of the phase II clinical trial indeed strongly support the antitumor effect of antiPD-1 antibody.

Armand et al. [60] investigated the effect of PD-1 blockade following autologous stem cell transplantation (ASCT) for relapsed or refractory DLBCL patients. The rationale was that the immune reconstitution that can occur post-ASCT may represent a good opportunity to try and break self-tolerance to DLBCL through PD-1 blockade. The investigators conducted a phase II trial using three doses of pidilizumab administered 1-3 months post-ASCT. The article assesses data from the 66 eligible patients in the study, of whom $55 \%$ showed evidence of active disease per PET before transplant. Among patients who remained positive on PET after salvage chemotherapy, the 16-month PFS was 0.70 . Impressively, of the 35 of patients with residual disease after ASCT and before the first dose of pidilizumab, $12(34 \%)$ achieved a complete remission and $6(17 \%)$ achieved a partial remission for an overall response rate of $51 \%$. An editorial on this article further analyzed the responses noted in this trial indicating that while it could be claimed that the noted responses could be a result of ongoing scarring or resolution of inflammation, the observation that $34 \%$ of patients with PET-positive disease post-ASCT experienced a remission after pidilizumab counters this argument.

Notably, treatment resulted in an early and sustained increase in PD-L1-expressing CD4+ and monocytes that suggests an on-target effect of the antibody. The editorial further indicated that, although the short-term toxicity of anti-PD-1 agents is not significant, there is still not enough information about the long-term effects of PD-1 axis blockade, and that drug-induced pneumonitis remains a concern [61].

\section{Conclusions}

The PD-1-PD-L1/PD-L2 axis is one of the immune checkpoint systems that work in concert with other checkpoints in order to prevent overreaction of the immune system and consequent tissue damage. Solid and hematological malignancies are exploiting this natural system in order to avoid destruction by the immune response. T- and B-cell lymphomas as well as MM express different levels of PD-1 and PD-L1 on the tumor-infiltrating lymphocytes and the tumor microenvironment, respectively. So far, clinical trials using antibodies to inhibit PD-1/PD-L1 interaction have demonstrated a significant level of clinical responses manifested in the extension of PFS and overall survival of patients with different malignancies. Although there is still a long way to go before we will be able to use these drugs in day-to-day practice for lymphoid malignancies, the approach appears to be promising.

References
1 Aruffo A, Seed B: Molecular cloning of a CD28 CDNA by a high-efficiency COS cell expression system. Proc Natl Acad Sci USA 1987;84:8573-8577.

2 Larsen CP, Ritchie SC, Hendrix R, Linsley PS, Hathcock KS, Hodes RJ, Lowry RP, Pearson TC: Regulation of immunostimulatory function and costimulatory molecule (B7-1 and B7-2) expression on murine dendritic cells. J Immunol 1994;152:5208-5219.

3 Vigano S, Perreau M, Pantaleo G, Harari A: Positive and negative regulation of cellular immune responses in physiologic conditions and diseases. Clin Dev Immunol 2012;2012:485781. 
4 Walker LS, Sansom DM: The emerging role of CTLA4 as a cell-extrinsic regulator of T-cell responses. Nat Rev Immunol 2011;11:852863.

5 Hodi FS, O’Day SJ, McDermott DF, Weber RW, Sosman JA, Haanen JB, Gonzalez R, Robert C, Schadendorf D, Hassel JC, Akerley W, van den Eertwegh AJ, Lutzky J, Lorigan P, Vaubel JM, Linette GP, Hogg D, Ottensmeier $\mathrm{CH}$, Lebbe C, Peschel C, Quirt I, Clark JI, Wolchok JD, Weber JS, Tian J, Yellin MJ, Nichol GM, Hoos A, Urba WJ: Improved survival with ipilimumab in patients with metastatic melanoma. N Engl J Med 2010;363:711723.

6 Wakamatsu E, Mathis D, Benoist C: Convergent and divergent effects of costimulatory molecules in conventional and regulatory CD4+ T cells. Proc Natl Acad Sci USA 2013; 110:1023-1028.

7 Cheng X, Veverka V, Radhakrishnan A, Waters LC, Muskett FW, Morgan SH, Huo J, Yu C, Evans EJ, Leslie AJ, Griffiths M, Stubberfield C, Griffin R, Henry AJ, Jansson A, Ladbury JE, Ikemizu S, Carr MD, Davis SJ: Structure and interactions of the human programmed cell death 1 receptor. J Biol Chem 2013;288:11771-11785.

8 Agata Y, Kawasaki A, Nishimura H, Ishida Y, Tsubata T, Yagita H, Honjo T: Expression of the PD-1 antigen on the surface of stimulated mouse $\mathrm{T}$ and $\mathrm{B}$ lymphocytes. Int Immunol 1996;8:765-772.

-9 Vivier E, Daeron M: Immunoreceptor tyrosine-based inhibition motifs. Immunol Today 1997; 18:286-291.

10 Ishida Y, Agata Y, Shibahara K, Honjo T: Induced expression of PD-1, a novel member of the immunoglobulin gene superfamily, upon programmed cell death. EMBO J 1992;11: 3887-3895.

11 Chemnitz JM, Parry RV, Nichols KE, June CH, Riley JL: SHP-1 and SHP-2 associate with immunoreceptor tyrosine-based switch motif of programmed death 1 upon primary human T-cell stimulation, but only receptor ligation prevents T-cell activation. J Immunol 2004; 173:945-954.

$\checkmark 12$ Nishimura H, Honjo T: PD-1: an inhibitory immunoreceptor involved in peripheral tolerance. Trends Immunol 2001;22:265-268.

$\checkmark 13$ Freeman GJ, Long AJ, Iwai Y, Bourque K, Chernova T, Nishimura H, Fitz LJ, Malenkovich N, Okazaki T, Byrne MC, Horton HF, Fouser L, Carter L, Ling V, Bowman MR, Carreno BM, Collins M, Wood CR, Honjo T: Engagement of the PD-1 immunoinhibitory receptor by a novel B7 family member leads to negative regulation of lymphocyte activation. J Exp Med 2000;192:1027-1034.

14 Greaves P, Gribben JG: The role of B7 family molecules in hematologic malignancy. Blood 2013;121:734-744.

15 Latchman Y, Wood CR, Chernova T, Chaudhary D, Borde M, Chernova I, Iwai Y, Long AJ, Brown JA, Nunes R, Greenfield EA, Bourque $\mathrm{K}$, Boussiotis VA, Carter LL, Carreno BM,
Malenkovich N, Nishimura H, Okazaki T, Honjo T, Sharpe AH, Freeman GJ: PD-L2 is a second ligand for PD-1 and inhibits T-cell activation. Nat Immunol 2001;2:261-268.

16 Quezada SA, Peggs KS: Exploiting CTLA-4, PD-1 and PD-L1 to reactivate the host immune response against cancer. $\mathrm{Br} J$ Cancer 2013;108:1560-1565.

17 Barber DL, Wherry EJ, Masopust D, Zhu B, Allison JP, Sharpe AH, Freeman GJ, Ahmed $\mathrm{R}$ : Restoring function in exhausted CD8 T cells during chronic viral infection. Nature 2006;439:682-687.

18 Petrovas C, Casazza JP, Brenchley JM, Price DA, Gostick E, Adams WC, Precopio ML, Schacker T, Roederer M, Douek DC, Koup RA: PD-1 is a regulator of virus-specific CD8+ T-cell survival in HIV infection. J Exp Med 2006;203:2281-2292.

$>19$ Nishimura H, Nose M, Hiai H, Minato N, Honjo T: Development of lupus-like autoimmune diseases by disruption of the PD-1 gene encoding an ITIM motif-carrying immunoreceptor. Immunity 1999;11:141-151.

20 Latchman YE, Liang SC, Wu Y, Chernova T, Sobel RA, Klemm M, Kuchroo VK, Freeman GJ, Sharpe AH: PD-L1-deficient mice show that PD-L1 on $\mathrm{T}$ cells, antigen-presenting cells, and host tissues negatively regulates $\mathrm{T}$ cells. Proc Natl Acad Sci USA 2004;101: 10691-10696.

21 Dong $\mathrm{H}$, Strome SE, Salomao DR, Tamura H, Hirano F, Flies DB, Roche PC, Lu J, Zhu G, Tamada K, Lennon VA, Celis E, Chen L: Tumor-associated B7-H1 promotes T-cell apoptosis: a potential mechanism of immune evasion. Nat Med 2002;8:793-800.

22 Thompson RH, Gillett MD, Cheville JC, Lohse CM, Dong H, Webster WS, Krejci KG, Lobo JR, Sengupta S, Chen L, Zincke H, Blute ML, Strome SE, Leibovich BC, Kwon ED: Costimulatory B7-H1 in renal cell carcinoma patients: Indicator of tumor aggressiveness and potential therapeutic target. Proc Natl Acad Sci USA 2004;101:17174-17179.

23 Hamanishi J, Mandai M, Iwasaki M, Okazaki T, Tanaka Y, Yamaguchi K, Higuchi T, Yagi H, Takakura K, Minato N, Honjo T, Fujii S: Programmed cell death 1 ligand 1 and tumorinfiltrating $\mathrm{CD} 8+\mathrm{T}$ lymphocytes are prognostic factors of human ovarian cancer. Proc Natl Acad Sci USA 2007;104:3360-3365.

24 Hino R, Kabashima K, Kato Y, Yagi H, Nakamura M, Honjo T, Okazaki T, Tokura Y: Tumor cell expression of programmed cell death-1 ligand 1 is a prognostic factor for malignant melanoma. Cancer 2010;116:1757-1766.

25 Sfanos KS, Bruno TC, Meeker AK, De Marzo AM, Isaacs WB, Drake CG: Human prostateinfiltrating CD8+ T lymphocytes are oligoclonal and PD-1+. Prostate 2009;69:1694-1703.

26 Ahmadzadeh M, Johnson LA, Heemskerk B, Wunderlich JR, Dudley ME, White DE, Rosenberg SA: Tumor antigen-specific CD8 $\mathrm{T}$ cells infiltrating the tumor express high levels of PD-1 and are functionally impaired. Blood 2009;114:1537-1544.
27 Curiel TJ, Wei S, Dong H, Alvarez X, Cheng P, Mottram P, Krzysiek R, Knutson KL, Daniel B, Zimmermann MC, David O, Burow M, Gordon A, Dhurandhar N, Myers L, Berggren R, Hemminki A, Alvarez RD, Emilie D, Curiel DT, Chen L, Zou W: Blockade of B7-H1 improves myeloid dendritic cell-mediated antitumor immunity. Nat Med 2003;9:562-567.

28 Khalili JS, Liu S, Rodriguez-Cruz TG, Whittington $\mathrm{M}$, Wardell S, Liu C, Zhang M, Cooper ZA, Frederick DT, Li Y, Joseph RW, Bernatchez C, Ekmekcioglu S, Grimm E, Radvanyi LG, Davis RE, Davies MA, Wargo JA, Hwu P, Lizee G: Oncogenic BRAF (V600E) promotes stromal cell-mediated immunosuppression via induction of interleukin-1 in melanoma. Clin Cancer Res 2012;18:53295340.

29 Pardoll DM: The blockade of immune checkpoints in cancer immunotherapy. Nat Rev Cancer 2012;12:252-264.

30 Brahmer JR, Tykodi SS, Chow LQM, Hwu WJ, Topalian SL, Hwu P, Drake CG, Camacho LH, Kauh J, Odunsi K, Pitot HC, Hamid O, Bhatia S, Martins R, Eaton K, Chen S, Salay TM, Alaparthy S, Grosso JF, Korman AJ, Parker SM, Agrawal S, Goldberg SM, Pardoll DM, Gupta A, Wigginton JM: Safety and activity of anti PD-L1 antibody in patients with advanced cancer. N Engl J Med 2012;366: 2455-2465.

31 Topalian SL, Hodi FS, Brahmer JR, Gettinger SN, Smith DC, McDermott DF, Powderly JD, Carvajal RD, Sosman JA, Atkins MB, Leming PD, Spigel DR, Antonia SJ, Horn L, Drake CG, Pardoll DM, Chen L, Sharfman WH, Anders RA, Taube JM, McMiller TL, Xu H, Korman AJ, Jure-Kunkel M, Agrawal S, McDonald D, Kollia GD, Gupta A, Wigginton JM, Sznol M: Safety, activity, and immune correlates of anti-PD-1 antibody in cancer. N Engl J Med 2012;366:2443-2454.

32 Sznol M, Kluger HM, Hodi FS, McDermott DF, Carvajal RD, Lawrence DP, Topalian SL, Atkins MB, Powderly JD, Sharfman WH: Survival and long-term follow-up of safety and response in patients with advanced melano$\mathrm{ma}$ in a phase I trial of nivolumab (anti-PD-1; BMS-936558; ONO-4538). J Clin Oncol 2013; 31:549S.

33 McDermott DF, Drake CG, Sznol M, Choueiri TK, Powderly J, Smith DC, Wigginton J, McDonald D, Kollia G, Gupta AK, Atkins MB: Clinical activity and safety of anti-PD-1 (BMS-936558, MDX-1106) in patients with previously treated metastatic renal cell carcinoma. J Clin Oncol 2012;30, abstract 4505.

34 Brahmer JR, Drake CG, Wollner I, Powderly JD, Picus J, Sharfman WH, Stankevich E, Pons A, Salay TM, McMiller TL, Gilson MM, Wang C, Selby M, Taube JM, Anders R, Chen L, Korman AJ, Pardoll DM, Lowy I, Topalian SL: Phase I study of single-agent anti-programmed death-1 (MDX-1106) in refractory solid tumors: safety, clinical activity, pharmacodynamics, and immunologic correlates. J Clin Oncol 2010;28:3167-3175. 
35 Patnaik A, Kang SP, Tolcher AW, Rasco DW, Papadopoulos KP, Beeram M, Drengler R, Chen C, Smith L, Perez C, Gergich K, Lehnert M: Phase I study of MK-3475 (anti-PD-1 monoclonal antibody) in patients with advanced solid tumors. ASCO Meeting Abstracts, 2012, vol 30, abstract 2512.

- 36 Kozako T, Yoshimitsu M, Fujiwara H, Masamoto I, Horai S, White Y, Akimoto M, Suzuki S, Matsushita K, Uozumi K, Tei C, Arima N: $\mathrm{PD}-1 / \mathrm{PD}-\mathrm{L} 1$ expression in human T-cell leukemia virus type 1 carriers and adult T-cell leukemia/lymphoma patients. Leukemia 2009;23:375-382.

-37 Xerri L, Chetaille B, Serriari N, Attias C, Guillaume Y, Arnoulet C, Olive D: Programmed death 1 is a marker of angioimmunoblastic Tcell lymphoma and B-cell small lymphocytic lymphoma/chronic lymphocytic leukemia. Hum Pathol 2008;39:1050-1058.

- 38 Andorsky DJ, Yamada RE, Said J, Pinkus GS, Betting DJ, Timmerman JM: Programmed death ligand 1 is expressed by non-Hodgkin lymphomas and inhibits the activity of tumor-associated T cells. Clin Cancer Res 2011; 17:4232-4244.

39 Brusa D, Serra S, Coscia M, Rossi D, D’Arena G, Laurenti L, Jaksic O, Fedele G, Inghirami G, Gaidano G, Malavasi F, Deaglio S: The PD-1/PD-L1 axis contributes to T-cell dysfunction in chronic lymphocytic leukemia. Haematologica 2013;98:953-963.

-40 Ramsay AG, Clear AJ, Fatah R, Gribben JG: Multiple inhibitory ligands induce impaired T-cell immunologic synapse function in chronic lymphocytic leukemia that can be blocked with lenalidomide: establishing a reversible immune evasion mechanism in human cancer. Blood 2012;120:1412-1421.

-41 Richendollar BG, Pohlman B, Elson P, Hsi ED: Follicular programmed death-1-positive lymphocytes in the tumor microenvironment are an independent prognostic factor in follicular lymphoma. Hum Pathol 2011;42:552557.

-42 Wahlin BE, Aggarwal M, Montes-Moreno S, Gonzalez LF, Roncador G, Sanchez-Verde L, Christensson B, Sander B, Kimby E: A unifying microenvironment model in follicular lymphoma: outcome is predicted by programmed death-1-positive, regulatory, cytotoxic, and helper $\mathrm{T}$ cells and macrophages. Clin Cancer Res 2010;16:637-650.

-43 Carreras J, Lopez-Guillermo A, Roncador G, Villamor N, Colomo L, Martinez A, Hamoudi R, Howat WJ, Montserrat E, Campo E: High numbers of tumor-infiltrating programmed cell death-1-positive regulatory lymphocytes are associated with improved overall survival in follicular lymphoma. J Clin Oncol 2009;27: 1470-1476.
44 Takahashi H, Tomita N, Sakata S, Tsuyama N, Hashimoto C, Ohshima R, Matsuura S, Ogawa K, Yamamoto W, Kameda Y, Enaka M, Inayama Y, Kasahara M, Takekawa Y, Onoda N, Motomura S, Ishigatsubo Y, Takeuchi K: Prognostic significance of programmed cell death-1-positive cells in follicular lymphoma patients may alter in the rituximab era. Eur J Haematol 2013;90:286-290.

45 Yang ZZ, Grote DM, Ziesmer SC, Ansell SM: $\mathrm{PD}-1$ expression defines two distinct T-cell subpopulations that differentially impact patient outcomes in follicular lymphoma. Blood 2013;122:366

46 Yamamoto R, Nishikori M, Kitawaki T, Sakai T, Hishizawa M, Tashima M, Kondo T, Ohmori K, Kurata M, Hayashi T, Uchiyama T: PD-1-PD-1 ligand interaction contributes to immunosuppressive microenvironment of Hodgkin lymphoma. Blood 2008;111:32203224.

47 Green MR, Monti S, Rodig SJ, Juszczynski P, Currie T, O’Donnell E, Chapuy B, Takeyama K, Neuberg D, Golub TR, Kutok JL, Shipp MA: Integrative analysis reveals selective 9p24.1 amplification, increased PD-1 ligand expression, and further induction via JAK2 in nodular sclerosing Hodgkin lymphoma and primary mediastinal large B-cell lymphoma. Blood 2010;116:3268-3277.

48 Chen BJ, Chapuy B, Ouyang J, Sun HH, Roemer MGM, Xu ML, Yu H, Fletcher CDM, Freeman GJ, Shipp MA, Rodig SJ: PD-L1 expression is characteristic of a subset of aggressive B-cell lymphomas and virus-associated malignancies. Clin Cancer Res 2013;19:34623473.

49 Grote DM, Ziesmer SC, Hodge LS, PriceTroska TL, Novak AJ, Yang ZZ: Interactions between $\mathrm{PD}-1$ and $\mathrm{PD}-\mathrm{L} 1$ and $\mathrm{PD}-\mathrm{L} 2$ promote malignant B-cell growth in Waldenström macroglobulinemia. Blood 2013;122:4334.

50 Iwai Y, Ishida M, Tanaka Y, Okazaki T, Honjo T, Minato N: Involvement of PD-L1 on tumor cells in the escape from host immune system and tumor immunotherapy by PD-L1 blockade. Proc Natl Acad Sci USA 2002;99: 12293-12297.

51 Liu J, Hamrouni A, Wolowiec D, Coiteux V, Kuliczkowski K, Hetuin D, Saudemont A, Quesnel B: Plasma cells from multiple myeloma patients express B7-H1 (PD-L1) and increase expression after stimulation with INF- $\gamma$ and TLR ligands via a MYD88-, TRAF6-, and MEK-dependent pathway. Blood 2007;110:296-304.

52 Hallett WH, Jing W, Drobyski WR, Johnson $\mathrm{BD}$ : Immunosuppressive effects of multiple myeloma are overcome by PD-L1 blockade. Biol Blood Marrow Transplant 2011;17: 1133-1145

-53 Kearl TJ, Jing W, Gershan JA, Johnson BD: Programmed death receptor-1/programmed death receptor ligand-1 blockade after transient lymphodepletion to treat myeloma. J Immunol 2013;190:5620-5628.
54 Benson DM Jr, Bakan CE, Mishra A, Hofmeister CC, Efebera Y, Becknell B, Baiocchi RA, Zhang J, Yu J, Smith MK, Greenfield CN, Porcu P, Devine SM, Rotem-Yehudar R, Lozanski G, Byrd JC, Caligiuri MA: The PD-1/ PD-L1 axis modulates the natural killer cell versus multiple myeloma effect: a therapeutic target for CT-011, a novel monoclonal antiPD-1 antibody. Blood 2010;116:2286-2294.

55 Luptakova K, Rosenblatt J, Glotzbecker B, Mills H, Stroopinsky D, Kufe T, Vasir B, Arnason J, Tzachanis D, Zwicker JI, Joyce RM, Levine JD, Anderson KC, Kufe D, Avigan D: Lenalidomide enhances anti-myeloma cellular immunity. Cancer Immunol Immunother 2013;62:39-49.

56 Berger R, Rotem-Yehudar R, Slama G, Landes S, Kneller A, Leiba M, Koren-Michowitz M, Shimoni A, Nagler A: Phase I safety and pharmacokinetic study of CT-011, a humanized antibody interacting with PD-1, in patients with advanced hematologic malignancies. Clin Cancer Res 2008;14:3044-3051.

57 Westin JR, Chu F, Foglietta M, Rotem-Yehudar R, Neelapu SS: Phase II safety and efficacy study of CT-011, a humanized anti-PD-1 monoclonal antibody, in combination with rituximab in patients with relapsed follicular lymphoma. ASCO Meeting Abstracts, 2010, vol 28, abstract TPS305.

58 Westin JR, Chu F, Zhang M, Fayad LE, Kwak LW, Fowler N, Romaguera J, Hagemeister F, Fanale M, Samaniego F, Feng L, Baladandayuthapani V, Wang Z, Ma W, Gao Y, Wallace M, Vence LM, Radvanyi L, Muzzafar T, Rotem-Yehudar R, Davis RE, Neelapu SS: Safety and activity of PD-1 blockade by pidilizumab in combination with rituximab in patients with relapsed follicular lymphoma: a single group, open-label, phase 2 trial. Lancet Oncol 2014;15:69-77.

59 Bachy E, Coiffier B: Anti-PD-1 antibody: a new approach to treatment of lymphomas. Lancet Oncol 2014;15:7-8.

60 Armand P, Nagler A, Weller EA, Devine SM, Avigan DE, Chen YB, Kaminski MS, Holland HK, Winter JN, Mason JR, Fay JW, Rizzieri DA, Hosing CM, Ball ED, Uberti JP, Lazarus HM, Mapara MY, Gregory SA, Timmerman JM, Andorsky D, Or R, Waller EK, RotemYehudar R, Gordon LI: Disabling immune tolerance by programmed death-1 blockade with pidilizumab after autologous hematopoietic stem-cell transplantation for diffuse large B-cell lymphoma: results of an international phase II trial. J Clin Oncol 2013;31: 4199-4206.

61 Jacobsen ED: Restoring antitumor immunity via $\mathrm{PD}-1$ blockade after autologous stem-cell transplantation for diffuse large B-cell lymphoma. J Clin Oncol 2013;31:4268-4270. 